\title{
Performance Appraisal of Human Resources in University Libraries --Taking the Library in Jiangxi University of Science and Technology as an Example
}

\author{
Jiezhu Nie ${ }^{1, a}$, Qiuwen Huang ${ }^{2, b}$, Ganghua Zhang ${ }^{3, c}$ \\ 1,2,3 Jiangxi University of Science and Technology \\ Ganzhou , 341000,China \\ aemail:azhu11@126.com, bemail:hqw3886@163.com, cemail:zgh06@126.com
}

Keywords: Library; Performance Appraisal; Model

\begin{abstract}
This paper has analyzed performance appraisal(PA) principles of human resources(HR) in universities, listed out PA indices and their significance, and structuralized PA model in theory. This model has been employed perfectly in evaluating the year 2011 annual performances of the HR in the library of Jiangxi University of Science and Technology (JUST) in China, which has greatly enhanced the PA quality and satisfied the staff in the school library.
\end{abstract}

\section{Background}

The factor of performances is one of the dimensions to assess university library development, and is also a lasting target for a library to achieve. And performance appraisal (PA) is a core measure of human resources (HR) managing, and a key for a library to compete with others successfully. PA, like a double-edged sword which will bring about prosperity by means of inspiring people with hope, strength, confidence and enthusiasm if employed properly, or cause the pessimizing of groups concentrating, and eventually, decreasing of productivity and efficiency, featuring a desiring quick success and a resorting to deceit, is a significant approach of HR managing if handled improperly. Therefore, a scientific and rational attitude toward PA is needed for people to enjoy a feasible, reliable and sustainable managing approach [1]. The appearing of performance income leads to a reform in the income distribution system of China. How to optimize the library PA of the HR in JUST is a matter of great urgency.

\section{Definition of PA}

Library PA, which has two other names including performance evaluation and performance assessment, refers to assessing and evaluating all the activities and desired targets of a library by means of qualitative and quantitative approaches [2]. According to the topic category, papers on library PA in China can be categorized into six groups, such as literature review, library PA abroad, research on the indices of library PA, methods and models of library PA, library alliance PA research, and evaluating details on library PA, including assessing the performance evaluation of digital library, library human resources, literature resources, specific work, services of a library, etc..

PA of Library HR refers to a process of ordered and even most objective testing and assessing the actual efficiency and the contribution as well as the value of staff performances based on scientific-and-reasonably qualitative and quantitative means [3]. This paper concerns research of the PA of library HR, and employ the means to evaluate the annual PA of the library in which the researcher works.

\section{Major points of PA}

A. PA principle

Firstly, the standard of PA concerns not the staff, but the positions themselves; secondly, the 
standard, which is reachable for most of the staff, is set for the majority of the staff; thirdly, the terms of the standard must be explicit, must not be implicit; fourthly, the standard should be enjoyed by means of negotiation; fifthly, the standard should involve describing specific conducts of the staff.

B. Various PA indices

1) Morality, including vocational and social aspects. (See Table 1)

TABLE 1 AsSESSING Factors ON MORALity

\begin{tabular}{|c|c|c|}
\hline \multirow{4}{*}{$\begin{array}{l}\text { Vocational } \\
\text { virtue }\end{array}$} & Political attitude & With proper political study attitude, concerning the growth of the library \\
\hline & Loving work spirit & $\begin{array}{l}\text { Loving work, loving readers, being model teacher, serving and fostering } \\
\text { the students, conducting everything unselfishly }\end{array}$ \\
\hline & Serving spirit & Serving and respecting readers with principles and proper approaches \\
\hline & Group spirit & $\begin{array}{l}\text { Maintaining personal ties actively, always being ready to offer others } \\
\text { help associating and cooperating with others effectively, being willing } \\
\text { to be others' helper, being good at raising future staff }\end{array}$ \\
\hline \multirow{2}{*}{$\begin{array}{l}\text { Social } \\
\text { virtue }\end{array}$} & $\begin{array}{l}\text { Conducting according laws } \\
\text { and regulations }\end{array}$ & Always abiding by social virtue principles \\
\hline & $\begin{array}{l}\text { Conducts and activities } \\
\text { Benefiting the public }\end{array}$ & Taking part in various kinds of benefiting the society and the public \\
\hline
\end{tabular}

2)

Ability, including working ability, working-related training and research ability . (See Table

TABLE 2 AsSESSING FACTORS ON ABILITY

\begin{tabular}{|c|l|}
\hline Working ability & $\begin{array}{l}\text { Loving study, renewing and utilizing practical knowledge in time, Being after better } \\
\text { achievements, improving professional skills actively }\end{array}$ \\
\hline Working-related training & Attending activities concerning training, meetings, virtue education,etc. \\
\hline Research ability & Writing papers, composing works, applying for research funding as well as rewarding \\
\hline
\end{tabular}

3) Manner, including attendance rate, on-time working, working attitude . (See Table 3)

TABLE 3 ASSESSING FACTORS ON MANNER

\begin{tabular}{|c|c|c|}
\hline $\begin{array}{l}\text { Attendance } \\
\text { frequency }\end{array}$ & \multicolumn{2}{|c|}{$\begin{array}{l}\text { Recording on time or asking for leaves } \\
\text { (Seeking permission from the library president if leaving 3-5days, from the school personnel } \\
\text { office if over } 5 \text { days ) }\end{array}$} \\
\hline On-time working & \multicolumn{2}{|c|}{$\begin{array}{l}\text { Sticking to positions, including no leaving, no strolling from one working site to another, no } \\
\text { conducting personal affairs, no chatting, }\end{array}$} \\
\hline \multirow{3}{*}{ Working attitude } & attitude & $\begin{array}{l}\text { Taking tasks and missions actively whether they are easy or } \\
\text { difficult }\end{array}$ \\
\hline & $\begin{array}{l}\text { Abiding policies and } \\
\text { regulations }\end{array}$ & $\begin{array}{l}\text { Carrying out one's own duty based on library working principles } \\
\text { and regulations }\end{array}$ \\
\hline & $\begin{array}{l}\text { Accepting labor } \\
\text { distribution }\end{array}$ & $\begin{array}{l}\text { Following instructions and arrangements, taking the whole into } \\
\text { consideration, no rejecting hard tasks }\end{array}$ \\
\hline
\end{tabular}

4) Outcome, including quality and quantity of products (See Table 4)

TABle 4 Assessing Factors on OUTCOME

\begin{tabular}{|c|c|l|}
\hline \multirow{4}{*}{ Quantity } & $\begin{array}{c}\text { Finishing state of working } \\
\text { tasks }\end{array}$ & \multicolumn{1}{c|}{ Quantity checking and ranking } \\
\cline { 2 - 3 } & Extra work & $\begin{array}{l}\text { Rewarding more or ranking higher based on the taking and finishing } \\
\text { temporary work from departments or the library actively }\end{array}$ \\
\hline \multirow{5}{*}{ Quality } & Working environment & $\begin{array}{l}\text { Cleaning the room, including wiping off the dirt from the floor, desks and } \\
\text { chairs; closing the door and the window after work, preventing fire } \\
\text { disasters from happening, keeping fire escape and hose normal, devices } \\
\text { with frequent cleaning and maintenance only for work, keeping library } \\
\text { tranquil by fixing mobile phones mute while working }\end{array}$ \\
\cline { 2 - 3 } & Error rate & Books being in order of categories \\
\cline { 2 - 3 } & Complaints of readers & Lowering scores based on facts \\
\cline { 2 - 3 } & Praise from readers & upping scores based on facts \\
\cline { 2 - 3 } & Particular position & Major figures who decide how to handle adding, lowering, etc \\
\hline
\end{tabular}

C. Index rate

The PA indices include morality(M),ability(A),manner (M')and outcome(O),mainly involving the results of the position duty, and focusing on actual working achievement, and taking attendance or the similar into account. Its overall value is 100 points, including $\mathrm{M}(10$ points), $\mathrm{A}(20$ points), M'(30 points), and $\mathrm{O}(40$ points). Any extra (X) points will become one part of the total value(P).

The PA results will be arranged according to the actual ranking value such as excellent, good, OK, so-so, and failure. Describe it using percentage as follows. (see Table 5) 


\begin{tabular}{|c|c|c|c|c|c|}
\hline Rank & Excellent & Good & OK & SO-so & Failure \\
\hline Percentage & $10 \%-11 \%$ & $20 \%-25 \%$ & $64 \%-70 \%$ & No limit & No limit \\
\hline
\end{tabular}

There are many indefinite indices in the process of PA. Assessors can alter indices and their significance partly, which will contribute to objective and reasonable PA results.

D. Structuralizing PA model in theory

Structuralization model is a kind of analysis tool for a library to describe the overall PA results of its staff and their exact relationship among all major factors [4]. It reveals the influencing degree between the relationship of the major factors and the PA results and the overall achievement. At present, the library of the school has taken the four aspects, M, A, M',O, as the major PA indices. Generally, the four aspects can completely reflect the overall state of the library staff. To employ this model to conduct the PA can not only decrease the complexity of the assessing process, but also achieve the PA fairness and justice. What's more, the three factors, M, A, M', are universal elements for people to conduct different kinds of PA. Meanwhile, $\mathrm{O}$ is a quite complicated aspect because different jobs involve different targets, characters, schedules and processes [5]. As a result, the indices that $\mathrm{O}$ involves vary with each other, and one must take careful examination, calculation, and assessment.

1) Structuralizing model (see Figure 1)

$$
P=M+A+M^{\prime}+O
$$

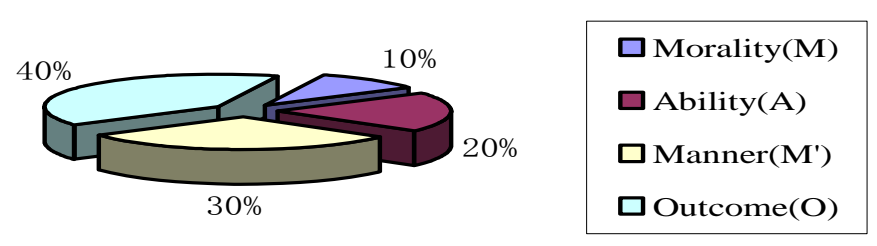

Figure 1 Structuralizing model(1)

2) Outline value model

$$
\mathrm{P}_{\text {total }}=\mathrm{M}+\mathrm{A}+\mathrm{M}^{\prime}+\mathrm{O}+\mathrm{X}
$$

Among which, $P_{\text {total }}$ is the overall score which indicates a general PA result. The values of $M$, $M^{\prime}, A$, O are from their individual assessment, and $X$ refers to adding or degrading.

E. PA feedback---accomplishing a harmonious development of the library

In order to show the feasibility of the PA model, now taking the library in JUST as an example, in 2012, using model (2), the PA results of the staff of the library numbered 54, are as follows. Six are excellent; thirteen are good; thirty-five are OK. None are so-so or failure. The staff are quite satisfied with the PA results due to the process being objective, fair, public, concentrating on actual outcome, easy to conduct, every index being based on concrete rules.

The aim of PA is not only to offer an annual score for each member, but to inspire and stimulate the staff to work harder and to achieve more in the future, and also an effective approach to improve service quality, and to better the daily management by means of annual PA [6]. On one hand, PA is now playing a very important role in realizing developing goals. On the other hand, people should take full consideration on PA shortage, and think over so many indices while conducting PA further, and to optimize the role of the PA [7]. The following are the writer's viewpoints on designing and realizing of PA system from the working experience in the library in JUST:

- First, design the indices according different fields, by qualitative and quantitative method.

- Second, concentrate on the key target concerning working achievements.

- Third, different position should involve different ranking items.

- Fourth, colleague assessment should be adopted wholly within a library.

- Fifth, take a consistent record about working regulations and principles. 
- Sixth, take both fairness and efficiency into account, and set a fundamental rank(score).

- Seventh, keep smooth communications during the course of PA.

\section{Conclusion}

Different libraries should design and conduct different PA standards according to their specific features of each individual library with both qualitative and quantitative approaches. Form an objective assessment for each member based upon their achievements and their contribution to the library as early as possible, which will help achieve PA goals. Appropriate and proper PA methods can optimize staff activeness, strengthen consolidating force, enhance staff professional ability, improve their working conducts, and further promote managing level and service quality of a library, and make it keep pace with the Times harmoniously and healthily.

\section{References}

[1] Changzhi Zhan, Hongxia Zhang. How does a dandelion seed from overseas root and thrive? The successful imp lementation of TQM in Hainan University Library[J]. Library Management, 2006 (27, 6 /7) , pp. 344 - 353.

[2] Xin-hong Chen, Yue-chen LI.Study on the Method of Librarian Contextual Performance Assessment Based on the Theory of Fuzzy Analytic Hierarchy Process[J]. Journal of Library and Information Sciences in Agriculture, 2011(4) , pp. 218-221

[3] Changshu Quan, Haiyan Jin. A Recommend on Performance Assessment of Academic Libraries[J]. Contemporary Library ,2010(3) , pp. 24-26

[4] Rhea Joyce Rubin. Demonstrating results: using outcome measurement in your library[J]. For the PLA ( Public Library Association) spring symposium, Mar, 2007.

[5] The Effective Academic Library: a framework for evaluating the performance of UK academic libraries: a joint consultative report to the HEFCE,SHEFC, HEFCW and DEN I by the Joint Funding Councils“Ad Hoc Group on Performance Indicators for Libraries. Bristol: Higher Education Funding Council for England, 1995.

[6] Xiang-jun Wang. Four-Dimensionality Checking Measure_—A Kind of Easy Year-End Checking Measure for the Librarian of Service Departments of the University Library[J]. Library Building .2009(3) , pp. 83-86

[7] Lei Zhang. View toward Achievement Evaluation of a Library[J]. Library Building,2007(7), pp. 98-101 